\title{
Screening for celiac disease in poorly controlled type 2 diabetes mellitus: worth it or not?
}

\author{
Muhammed Kizilgul ${ }^{1,2^{*}}$, Ozgur Ozcelik', Selvihan Beysel ${ }^{1}$, Hakan Akinci $^{3}$, Seyfullah Kan', Bekir Ucan',
} Mahmut Apaydin ${ }^{1}$ and Erman Cakal $^{1}$

\begin{abstract}
Background: Recent studies have demonstrated that immune factors might have a role in the pathophysiology of insulin resistance and type 2 diabetes mellitus (T2DM). Inappropriate glycemic control in patients with T2DM is an important risk factor for the occurrence of diabetes complications. The prevalence of celiac disease (CD) is high in type 1 diabetes mellitus however, there are scarce data about its prevalence in T2DM. Our aim was to investigate the prevalence of celiac disease among insulin-using type 2 diabetes patients with inappropriate glycemic control.

Methods: IgA tissue transglutaminase antibodies (tTGA IgA) test was performed as a screening test. A total of 135 patients with T2DM whose control of glycemia is inappropriate (HbAlc value $>7 \%$ ) in spite of using insulin treatment for at least 3-months (only insulin or insulin with oral antidiabetic drugs) and 115 healthy controls were enrolled in the study. Upper gastrointestinal endoscopy with duodenal biopsy was performed to all patients with raised tTGA IgA or selective IgA deficiency.

Results: Gender, age, body mass index (BMI) and tTGA IgA, kreatinin, calcium, LDL-cholesterol (LDL-C), total cholesterol, $25-\mathrm{OH}$ vitamin $\mathrm{D}_{3}$ levels were similar between groups. Systolic and diastolic blood pressure, waist circumference, fasting plasma glucose, postprandial plasma glucose, urea, sodium, HbA1c, LDL-C, triglyceride, vitamin B12 levels were significantly higher in DM group $(p<0.0001)$. BMI, high-sensitive CRP, microalbuminuria, and AST, ALT, potassium, phosphorus levels were significantly higher in the T2DM group $(p<0.05)$. HDL-cholesterol and parathormone levels were significantly lower in the T2DM group $(p<0.05)$. Two of the 135 patients with T2DM were diagnosed with CD (1.45\%).

Conclusions: The prevalence of celiac disease among patients with type 2 diabetes, with poor glycemic control despite insulin therapy, is slightly higher than the actual CD prevalence in general population. Type 2 diabetic patients with inappropriate control of glycemia in spite of insulin treatment might be additionally tested for Celiac disease especially if they have low C-peptide levels.
\end{abstract}

Keywords: Type 2 diabetes mellitus, Celiac disease, Tissue transglutaminase antibody

\footnotetext{
* Correspondence: muhammedkzgl@gmail.com; mkizilgu@umn.edu ${ }^{1}$ Department of Endocrinology and Metabolism, Diskapi Training and Research Hospital, Ankara, Turkey

${ }^{2}$ Schulze Diabetes Institute, University of Minnesota, Minneapolis, MN, USA

Full list of author information is available at the end of the article
}

(c) The Author(s). 2017 Open Access This article is distributed under the terms of the Creative Commons Attribution 4.0 International License (http://creativecommons.org/licenses/by/4.0/, which permits unrestricted use, distribution, and reproduction in any medium, provided you give appropriate credit to the original author(s) and the source, provide a link to the Creative Commons license, and indicate if changes were made. The Creative Commons Public Domain Dedication waiver (http://creativecommons.org/publicdomain/zero/1.0/) applies to the data made available in this article, unless otherwise stated. 


\section{Background}

Type 2 diabetes mellitus (T2DM), a chronic metabolic disorder, is an important community health problem in which prevalence has been increasing steadily all over the world [1]. Celiac disease (CD), a chronic autoimmune disease, is described as small intestinal inflammation and villous atrophy (VA) induced by gluten exposure in genetically susceptible people [2] and its prevalence approximately reaches $1 / 100$ in western European countries [3]. A recent meta-analysis demonstrated that more than 1 in 20 patients with type 1 diabetes (T1DM) had celiac disease confirmed by biopsy [4]. Serology has a key role in the diagnosis of CD. Evaluating IgA tissue transglutaminase antibody (tTGA) is now considered as the best strategy for CD serological screening since it has the highest sensitivity in diagnosing of CD (up to \% 97) [5]. The impaired beta-cell function is accepted as the main physiopathological mechanism for overt type 2 diabetes; however, the leading cause of this disease remains unknown [6]. Recent studies have demonstrated that both innate immune and adaptive immune system might have a role in the pathophysiology of insulin resistance and T2DM [7]. Insulin resistance and progressive loss of insulin secretion capacity due to either beta-cell dysfunction and/or betacell loss are main characteristics of T2DM [8]. High-fat diet related secretion of proinflammatory cytokines [9], endoplasmic reticulum stress via activation of toll-like receptors [10-12], activation of NLRP3 inflammasome upregulation [13] and promotion of glucose homeostasis by TNF- $\alpha$ blocker [14], the association of insulin resistance and dietary fatty acids with activation of $\mathrm{B}$ and $\mathrm{T}$ lymphocytes [15-17] are all evidence which may suggest the role of autoimmunity in the etiopathogenesis of T2DM. Few studies have investigated the prevalence of $\mathrm{CD}$ in patients with T2DM [18-20]. However, only one study investigated tTGA prevalence in patients with T2DM, which demonstrated tTGA positivity in $11 \%$ of patients [21]. It is wellknown that good glycemic control in diabetes decreases both the microvascular and macrovascular complications [22] however, many patients still have poor glycemic control [23]. Inappropriate glycemic control in patients with T2DM is an important risk factor for the occurrence of diabetes complications [24]. Patient and health care professional associated factors might have a role in poor glycemic control [25].

The purpose of this paper was to evaluate the prevalence of tTGA IgA positivity and possible celiac disease in T2DM patients with poor glycemic control (HbAlc value $>7 \%$ ) despite receiving insulin treatment.

\section{Methods}

We studied the frequency of tTGA IgA in patients with T2DM $(n=135)$ whose control of glycemia is inappropriate (HbAlc value $>7 \%$ ) in spite of using insulin therapy for at least 3-months (only insulin or insulin with oral antidiabetic drugs) and healthy controls ( $n=115)$ attending the endocrinology outpatient clinic of Diskapi Training and Research Hospital in Turkey. Ethical standards of the Helsinki Declaration were followed. Approval of ethical committee in Diskapi Training and Research Hospital (Date: 26.01.2015, Decree No:19/36) and written informed consent of participants were obtained before the study. All treatments that patients received are considered standard care for their condition.

All patients with raised tTGA IgA and those with selective IgA deficiency were invited for further assessment. A medical history and evidence of diabetic complications were noted, together with an evaluation of gastrointestinal symptoms using a questionnaire administered by a single observer. Upper gastrointestinal endoscopy with duodenal biopsy was offered to all patients with raised tTGA IgA or selective lgA deficiency. Endoscopy was performed under sedation, and multiple biopsies were obtained from the second part of the duodenum or beyond. All biopsies were examined histologically according to Marsh's criteria [26] by a single observer at the Department of Pathology who was unaware of the tTGA IgA titer. Those patients whose biopsies showed total or severe partial villous atrophy were regarded as having celiac disease. Autoantibodies (Anti-islet cell antibody, anti-insulin antibody, and antiGAD antibody) were assessed in the patients diagnosed with $\mathrm{CD}$. Patients with $\mathrm{CD}$ received advice about a glutenfree diet. Supplemental iron, folic acid, and calcium were prescribed as appropriate. Clinical, hematological and biochemical assessments were carried out every three months to evaluate the response to withdrawal of gluten. Direct questioning monitored dietary compliance. Demographic data and medical history of all individuals including diabetes duration, treatment protocol were noted; anthropometric measurements were carried out. Weight, height, waist circumference (WC), hip circumference $(\mathrm{HC})$ and systolic and diastolic blood pressure (BP) were measured. Dividing the weight by the height squared $(\mathrm{kg} / \mathrm{m} 2)$ was used for the measurement of the body mass index (BMI). WC was determined by measuring the narrowest point between the lowest rib and iliac crest at minimal normal respiration. A standard mercury sphygmomanometer was used for the measurement of the blood pressure (BP), with the patient at rest and in the sitting posture for at least $10 \mathrm{~min}$. The average of two calculations was noted.

Measurement of anti-tissue transglutaminase antibodies (tTGA) Tissue transglutaminase antibodies were measured using a human tTG enzyme-linked immunosorbent assay (ELISA) kit (AESKULISA, Aesku.lab Diagnostka, Wendelsheim, 
Germany). The intra-assay and inter-assay coefficient of variation were both lower than $10 \%$.

Serum IgA levels of CD patients and healthy controls were measured for the exclusion of IgA deficiency. IgA level of lower than $0.05 \mathrm{~g} / \mathrm{L}$, indicative of selective IgA deficiency, was not observed in any cases.

\section{Statistical analysis}

Statistical analysis was performed using JMP 11.0.0 software (SAS Institute, Cary, NC). Variables are presented as mean \pm standard deviation (SD) or median (min-max), percentage (\%). Normality was tested by KolmogorovSmirnov and Shapiro-Wilk W test. A two-sample $t$-test or one-way ANOVA were used for comparison of numerical means. Mann-Whitney U test was used for continuous variables between diabetes with and without celiac disease. The Chi-square test or Fisher's exact test was used for categorical variables. Statistical significance was defined as a $p<0.05$.

\section{Results}

One hundred thirty-five subjects with T2DM and 115 healthy individuals were enrolled in the study. All patients underwent a first screening step for CD using tTGA IgA test. 3 patients $(2.2 \%)$ in DM group and 1 patient $(0.9 \%)$ in control group had increased level of tTGA IgA. These patients underwent upper gastrointestinal endoscopy with duodenal biopsy and anti-endomysial antibodies test. Two of the patients in DM group was diagnosed with $C D$ (1.45\%) (Tables 1 and 2). Autoantibodies (anti-islet cell antibody, anti-insulin antibody, and anti-GAD antibody) were assessed in the patients diagnosed with celiac disease. Both patients had negative results for anti-GAD, anti-insulin, and anti-islet cell antibodies. Gender, age, BMI and tTGA IgA, kreatinin, calcium, LDL-cholesterol,

Table 1 Demographic and clinical characteristics of patients

\begin{tabular}{lllllll}
\hline & \multicolumn{3}{l}{ Groups } \\
& \multicolumn{4}{l}{ DM (n:135) } & \multicolumn{3}{l}{ Control (n:115) } \\
Gender & $n$ & $\%$ & $n$ & $\%$ & $p$ \\
Female & 90 & 67 & 82 & 71 & 0.430 \\
Male & 45 & 33 & 33 & 29 & \\
Celiac Disease & 2 & 1.45 & 0 & 0 & 0.501 \\
& Mean & Std Dev & Mean & Std Dev & $p$ \\
Age (yrs) & 52.7 & 6.8 & 50.9 & 8.1 & 0.069 \\
SBP (mmHg) & 129.5 & 15.4 & 114.4 & 13.6 & $<0.0001$ \\
DBP (mmHg) & 80.5 & 9.9 & 71.2 & 9.1 & $<0.0001$ \\
BMI (kg/m²) & 32.4 & 12.3 & 28.0 & 4.7 & 0.0002 \\
WC (cm) & 102.3 & 13.0 & 93.0 & 11.3 & $<0.0001$ \\
Duration of Diabetes (yrs) & 12.1 & 7.1 & - & - & \\
Total Insulin Dose (u) & 54.7 & 30 & - & - & \\
\hline
\end{tabular}

Table 2 Biochemical parameters of the study population

\begin{tabular}{|c|c|c|c|c|c|}
\hline \multirow[t]{3}{*}{ Groups } & \multirow{2}{*}{\multicolumn{2}{|c|}{ DM (n:135) }} & \multirow{2}{*}{\multicolumn{2}{|c|}{ Control (n:115) }} & \multirow[b]{3}{*}{$p$} \\
\hline & & & & & \\
\hline & Mean & Std Dev & Mean & Std Dev & \\
\hline tTGA IgA (U/mL) & 7.5 & 27.3 & 3.8 & 3.8 & 0.128 \\
\hline hsCRP & 8.0 & 8.8 & 3.7 & 10.5 & 0.003 \\
\hline FPG & 219.0 & 82.5 & 94.9 & 10.9 & $<0.0001$ \\
\hline PBG & 307.0 & 82.8 & 109.3 & 23.1 & $<0.0001$ \\
\hline Urea & 31.1 & 9.5 & 26.6 & 7.5 & $<0.0001$ \\
\hline Kreatinin & 0.9 & 0.2 & 0.9 & 0.1 & 0.255 \\
\hline AST & 25.0 & 13.9 & 21.0 & 5.6 & 0.006 \\
\hline ALT & 27.5 & 20.0 & 21.0 & 10.6 & 0.0013 \\
\hline Sodium & 137.4 & 2.3 & 139.2 & 1.7 & $<0.0001$ \\
\hline Potassium & 4.6 & 0.4 & 4.5 & 0.4 & 0.0005 \\
\hline Calcium & 9.6 & 0.4 & 9.6 & 0.4 & 0.756 \\
\hline Phosphorus & 3.7 & 0.6 & 3.4 & 0.6 & 0.0003 \\
\hline $\mathrm{HbA} 1 \mathrm{c}$ & 10.0 & 1.8 & 5.5 & 0.3 & $<0.0001$ \\
\hline LDL-C & 142.7 & 34.1 & 141.5 & 37.6 & 0.858 \\
\hline $\mathrm{HDL}-\mathrm{C}$ & 43.4 & 9.6 & 49.5 & 10.2 & $<0.0001$ \\
\hline Total-C & 194.7 & 43.0 & 199.7 & 44.8 & 0.349 \\
\hline TG & 215.3 & 153.3 & 136.0 & 76.7 & $<0.0001$ \\
\hline Microalbuminuria & 42.4 & 73.5 & 17.0 & 24.8 & 0.0178 \\
\hline 25-OHVitD3 & 16.7 & 14.7 & 15.9 & 14.7 & 0.566 \\
\hline PTH & 46.1 & 21.2 & 58.3 & 24.8 & 0.0006 \\
\hline Vitamin B12 & 303.7 & 210.5 & 207.6 & 82.2 & $<0.0001$ \\
\hline
\end{tabular}

total cholesterol, 25-OH vitamin $\mathrm{D}_{3}$ levels were similar between groups. SBP, DBP, WC and fasting plasma glucose (FPG), postprandial plasma glucose (PPPG), urea, sodium, HbA1c, LDL-C, TG, vitamin B12 levels were significantly higher in DM group $(p<0.0001)$. BMI, hsCRP, microalbuminuria and AST, ALT, potassium, phosphorus levels were significantly higher in DM group $(p<0.05)$. HDL-C and parathormone $(\mathrm{PTH})$ levels were significantly lower in DM group $(p<0.05)$. Plasma tTGA IgA concentrations were positively correlated with hsCRP (r:0.2138, $p: 0.0285)$ and HbA1c (r:0.197, p:0.0221). Plasma tTGA IgA concentrations were negatively correlated with LDL-cholesterol (r:-0.197, $p: 0.0232)$ and total cholesterol (r:-0.193, $p: 0.0367)$ (Table 3).

The diabetic patients were divided into three groups according to the C-peptide concentrations. The cut-off point of 0.51 was assumed. The first group consists of $12 \mathrm{pa}-$ tients with c-peptide level (normal range:0.51-2.7 ng/mL) lower than $0.51 \mathrm{ng} / \mathrm{mL}$, the second group consists of 22 patients with a c-peptide level between $0.51-1.0 \mathrm{ng} / \mathrm{m} \mathrm{L}$ and third group consist of 66 patients with c-peptide level higher than $1.0 \mathrm{ng} / \mathrm{mL}$. The mean c-peptide concentrations were significantly different between groups $(0.24 \pm 0.23$, $0.78 \pm 0.17,2.17 \pm 0.10$, respectively, $p<0.0001)$. The mean 
Table 3 The correlation between tTGA levels and clinical, biochemical and hormonal parameters in DM group

\begin{tabular}{|c|c|c|}
\hline Variable & $\begin{array}{l}\text { Correlation } \\
\text { coefficient }\end{array}$ & $p$-value \\
\hline Age & -0.057 & 0.513 \\
\hline SBP & 0.0094 & 0.9162 \\
\hline DBP & -0.0004 & 0.996 \\
\hline BMl & -0.0162 & 0.854 \\
\hline WC & 0.0528 & 0.5603 \\
\hline Duration of DM & -0.0336 & 0.7025 \\
\hline Total insulin use & -0.0318 & 0.7288 \\
\hline Anti-TPO & -0.0107 & 0.9138 \\
\hline Anti-Tg & -0.0104 & 0.9183 \\
\hline hsCRP & 0.2138 & 0.0285 \\
\hline FPG & -0.0382 & 0.6615 \\
\hline PPG & 0.0428 & 0.689 \\
\hline Urea & 0.1641 & 0.0698 \\
\hline Creatinine & 0.0243 & 0.781 \\
\hline AST & -0.0776 & 0.4054 \\
\hline ALT & -0.0826 & 0.3467 \\
\hline $\mathrm{HbA1c}$ & 0.1976 & 0.0221 \\
\hline LDL-Cholesterol & -0.1974 & 0.0232 \\
\hline HDL-Cholesterol & 0.0858 & 0.3494 \\
\hline Total-Cholesterol & -0.1933 & 0.0367 \\
\hline TG & -0.0785 & 0.3712 \\
\hline C-peptide & -0.137 & 0.1739 \\
\hline
\end{tabular}

tTGA concentrations between groups were significantly different between groups (36.44 \pm 8.67, 5.14 \pm 6.41, $4.56 \pm 3.70$, respectively, $p<0.0039)$. Age, SBP, DBP, $\mathrm{BMI}, \mathrm{WC}$, duration of diabetes, total insülin dose and hsCRP, FPG, PPG, HbA1c were similar between groups $(p>0.05)$ (Table 4).

\section{Discussion}

Accumulating evidence have suggested that both innate immune and adaptive immune system might have a role in the etiopathogenesis of T2DM. Circulating autoantibodies observed in T2DM may be a sign of autoimmune involvement. Expression of several $\beta$-cell antigens such as antiGAD was increased by hyperglycemia and anti-GAD is the most frequently determined antibodies in phenotypic T2DM [27]. IL-1 $\beta$ is known to cause both pancreatic $\beta$ cells impairment and destruction during the type 1 diabetes mellitus development. In human $\beta$ cells, high levels of glucose cause production and release of IL-1 $\beta$, which leads to upregulation of Fas receptor, NF- $\mathrm{B}$ activation, apoptosis and impaired function of the $\beta$ cell $[28,29]$. B cells in T2DM patients could not produce anti-inflammatory interleukin10 (IL-10), is effective in the control of autoimmune conditions, as a response to TLR2, TLR4 or TLR9 stimulation [30]. Therefore, decrease in IL-10 secretion as a response to stimulation by lipopolysaccharide leads to higher risk for T2DM development in elderly subjects [31].

Eventually, all these inflammatory and autoimmune pathways may lead to $\beta$-cell apoptosis and a further

Table 4 Demographic, biochemical and clinical characteristics of diabetic patients when they divided into 3 categories based on their c-peptide concentrations

\begin{tabular}{|c|c|c|c|c|c|c|c|}
\hline & \multicolumn{2}{|c|}{$\begin{array}{l}\text { 1st group } \\
\text { (n:13) }\end{array}$} & \multicolumn{2}{|c|}{$\begin{array}{l}\text { 2nd group } \\
\text { (n:22) }\end{array}$} & \multicolumn{2}{|c|}{$\begin{array}{l}\text { 3rd group } \\
\text { (n:66) }\end{array}$} & \multirow[b]{2}{*}{$p$-value } \\
\hline & Mean & SD & Mean & SD & Mean & SD & \\
\hline Age (yrs) & 53.38 & 5.28 & 56.64 & 6.06 & 54.08 & 8.79 & 0.362 \\
\hline $\mathrm{SBP}(\mathrm{mmHg})$ & 126.15 & 17.58 & 127.62 & 11.36 & 130.00 & 16.13 & 0.647 \\
\hline $\mathrm{DBP}(\mathrm{mmHg})$ & 77.69 & 12.35 & 79.29 & 7.79 & 80.94 & 10.19 & 0.518 \\
\hline BMI $\left(\mathrm{kg} / \mathrm{m}^{2}\right)$ & 28.54 & 4.43 & 29.86 & 4.07 & 34.45 & 16.47 & 0.210 \\
\hline$W C(\mathrm{~cm})$ & 95.85 & 15.85 & 101.50 & 7.80 & 103.53 & 14.04 & 0.168 \\
\hline Duration of Diabetes (yrs) & 14.77 & 9.79 & 13.82 & 6.10 & 11.02 & 6.86 & 0.108 \\
\hline Total Insulin Dose (u) & 54.46 & 25.09 & 62.10 & 34.98 & 53.76 & 27.59 & 0.535 \\
\hline tTGA IgA (U/mL) & 36.44 & 88.13 & 5.15 & 6.39 & 4.57 & 4.64 & 0.004 \\
\hline hsCRP & 5.20 & 8.60 & 6.74 & 5.63 & 7.85 & 7.63 & 0.579 \\
\hline FPG & 227.69 & 153.26 & 200.00 & 66.04 & 217.89 & 71.14 & 0.591 \\
\hline PBG & 274.71 & 128.90 & 322.21 & 88.55 & 304.83 & 80.31 & 0.506 \\
\hline $\mathrm{HbA1c}$ & 10.13 & 2.08 & 10.69 & 1.93 & 9.69 & 1.70 & 0.080 \\
\hline C-peptide & 0.24 & 0.20 & 0.78 & 0.14 & 2.18 & 1.01 & $<.0001$ \\
\hline
\end{tabular}

The first group consists of patients with c-peptide level (normal range: $0.51-2.7 \mathrm{ng} / \mathrm{mL}$ ) lower than $0.51 \mathrm{ng} / \mathrm{mL}$, the second group consists of patients with a c-peptide level between $0.51-1.0 \mathrm{ng} / \mathrm{m} \mathrm{L}$ and third group consist of a c-peptide level higher than $1.0 \mathrm{ng} / \mathrm{mL}$ 
decrease in insulin levels. In light of this information, we aimed to investigate whether tissue transglutaminases and consequently CD may have a role in the explanation of poorly controlled diabetes. In our study, CD prevalence was slightly higher in patients with poorly controlled diabetes than in healthy individuals.

Transglutaminase catalyzes the posttranslational modification of proteins via catalyzing calcium-dependent acyl transfer reaction [32]. The presence of transglutaminases has been demonstrated in several endocrine glands including pituitary gland, thymus genital tract of the male, human normal and pathologic adrenal tissues and pancreatic islet cells. tTGA may have effected the function $\beta$-cells [33]. Transglutaminases participate in the dynamic events that controlling exocytosis of single secretory granules in the $\beta$-cells [34]. The activity of transglutaminase has an essential role in the insulin release by glucose [35].

Since tTGA IgA is very sensitive and specific in diagnosing of $\mathrm{CD}$, it is a preferred screening test for $\mathrm{CD}$ [36]. Studies demonstrated that up to $12 \%$ of patients with T1DM screen positive for tTGA [37] however, there were scarce data about tTGA IgA prevalence in T2DM. Sjöberg et al. analyzed the presence of gliadin antibodies (GA) and endomysial antibodies (EMA) in patients with non-insulin dependent diabetes mellitus (NIDDM). Small bowel biopsy was performed to all EMA-positive diabetic patients. 92 (12.3\%) patients with NIDDM had IgA-GA positivity, 1 patient has EMA positivity and 2 patients with NIDDM (2/745) was diagnosed with CD [18]. Page et al. investigated the presence of lgA-AGA in 769 T1DM and 1020 T2DM patients, and 73 had a high lgA-AGA level. Forty-nine of 73 patients agreed to a duodenal biopsy, and 13 (10 T1DM, 3 T2DM) were diagnosed with $\mathrm{CD}$. The overall prevalence of $\mathrm{CD}$ in T2DM adult patients was found to be 1:340 [19]. Tourniaire et al. evaluated the presence of plasma gliadin antibodies in 80 type 1 diabetics, 80 type 2 diabetics, 80 non-diabetics without known auto-immune disease. IgA antibodies were observed in 6 type 1 diabetics (7.5\%), 8 type 2 diabetics $(10 \%)$ and 6 non-diabetics (7.5\%) and only one patient were diagnosed with $C D$ [20]. Kanungo et al. studied the frequency of TGA-Ab in patients with T2DM. 23 of 216 (11\%) with T2DM were positive for TGA-Ab [21]. Usai et al. investigated the presence of IgA antigliadin antibodies (AGA) in 29 patients with T2DM, and no high AGA level observed [38]. In another study, the presence of AGA, tTGA was investigated in 43 subjects with latent autoimmune diabetes of adult (LADA) and 99 with T2DM. 4 (4.0\%) of T2DM and $2(4.6 \%)$ of LADA were found to be tTGA positive. The authors concluded CD did not seem to be associated with pancreatic autoimmunity in T2DM. Biopsy confirmation was not performed in this particular study [39].
In our study, the prevalence of $\mathrm{CD}$ disease was slightly higher than the actual prevalence of $\mathrm{CD}$ in general population. Patients with lower c-peptide levels in DM group had higher levels of tTGA IgA. This finding might suggest that type 2 diabetic patients with lower cpeptide levels, which possibly have a more autoimmune component of the disease, could have more prevalence of celiac disease.

\section{Conclusions}

The prevalence of celiac disease in type 2 diabetes patients with inappropriate control of glycemia in spite of the insulin therapy, is slightly higher than the actual $C D$ prevalence in general population. Type 2 diabetic patients with poor control of glycemia in spite of insulin treatment might be additionally tested for Celiac disease if they have low C-peptide levels. However, further prospective population-based studies are required for confirming this thesis.

\section{Abbreviations \\ BMI: Body mass index; CD: Celiac disease; DBP: Diastolic blood pressure; EMA: Anti endomysium antibody; ERS: Endoplasmic reticulum stress; FPG: Fasting plasma glucose; HC: Hip circumference; HLD-C: HDL cholesterol; LDL-C: LDL-cholesterol; NIDDM: Non-insulin dependent diabetes mellitus; PPPG: Post-prandial plasma glucose; SBP: Systolic blood pressure; T2DM: Type 2 diabetes mellitus; TLR: Tool-like receptors; tTGA IgA: Tissue transglutaminase antibody IgA; VA: Villous atrophy; WC: Waist circumference}

\section{Acknowledgments}

None

\section{Funding \\ None}

\section{Availability of data and materials}

The datasets used and/or analysed during the current study available from the corresponding author on reasonable request.

\section{Authors' contributions}

MK: have made contributions to conception and design, acquisition of data, and analysis and interpretation of data. OO, SB, SK, BU: have made contributions to acquisition of data and interpretation of data. HA, MA: have made contributions to acquisition of data. MK, SB: performed the statistical analysis. EC: have made contributions to conception, design, and interpretation of data. All authors read and approved the final manuscript.

\section{Ethics approval and consent to participate}

Approval of ethical committee in Diskapi Training and Research Hospital and written informed consent of participants were obtained before the study (Date: 26. 01. 2015, Reference No:19/36).

\section{Consent for publication}

Non applicable

\section{Competing interests}

The authors declare that they have no conflict of interest.

\section{Publisher's Note}

Springer Nature remains neutral with regard to jurisdictional claims in published maps and institutional affiliations.

\section{Author details}

${ }^{1}$ Department of Endocrinology and Metabolism, Diskapi Training and Research Hospital, Ankara, Turkey. ${ }^{2}$ Schulze Diabetes Institute, University of 
Minnesota, Minneapolis, MN, USA. ${ }^{3}$ Department of Gastroenterology, Diskapi Training and Research Hospital, Ankara, Turkey.

\section{Received: 10 December 2016 Accepted: 2 October 2017 Published online: 06 October 2017}

\section{References}

1. Guariguata L. By the numbers: new estimates from the IDF Diabetes Atlas Update for 2012. Diabetes Res Clin Pract. 2012;98:524-5.

2. Green PH, Jabri B. Coeliac disease. Lancet. 2003;362:383-91.

3. Dube C, Rostom A, Sy R, Cranney A, Saloojee N, Garritty C, et al. The prevalence of celiac disease in average-risk and at-risk Western European populations: a systematic review. Gastroenterology. 2005;128(4 Suppl 1):S57-67.

4. Elfström P, Sundström J, Ludvigsson JF. Systematic review with meta-analysis: associations between coeliac disease and type 1 diabetes. Aliment Pharmaco Ther. 2014;40:1123-32.

5. Volta U, Fabbri A, Parisi C, Piscaglia M, Caio G, Tovoli F, et al. Old and new serological tests for celiac disease screening. Expert Rev Gastroenterol Hepatol. 2010;4:31-5.

6. Ashcroft FM, Rorsman P. Diabetes mellitus and the beta cell: the last ten years. Cell. 2012;148:1160-71.

7. Velloso LA, Eizirik DL, Cnop M. Type 2 diabetes mellitus-an autoimmune disease? Nat Rev Endocrinol. 2013;9:750-5.

8. Kahn SE. The relative contributions of insulin resistance and beta-cell dysfunction to the pathophysiology of Type 2 diabetes. Diabetologia. 2003;46:3-19.

9. Spranger J, Kroke A, Möhlig M, Hoffmann K, Bergmann MM, Ristow M, et al. Inflammatory cytokines and the risk to develop type 2 diabetes: results of the prospective population-based European prospective investigation into cancer and nutrition (EPIC)-potsdam study. Diabetes. 2003;52:812-7.

10. Tsukumo DM, Carvalho-Filho MA, Carvalheira JB, Prada PO, Hirabara SM, Schenka AA, et al. Loss of function mutation in Toll-like receptor 4 prevents diet-induced obesity and insulin resistance. Diabetes. 2007:56:1986-98.

11. Ozcan U, Cao Q, Yilmaz E, Lee AH, Iwakoshi NN, Ozdelen E, et al. Endoplasmic reticulum stress links obesity, insulin action, and type 2 diabetes. Science. 2004:306:457-61.

12. Milanski M, Degasperi G, Coope A, Morari J, Denis R, Cintra DE, et al. Saturated fatty acids produce an inflammatory response predominantly through the activation of TLR4 signaling in hypothalamus: implications for the pathogenesis of obesity. J Neurosci. 2009;29:359-70.

13. Masters SL, Dunne A, Subramanian SL, Hull RL, Tannahill GM, Sharp FA, et al. Activation of the NLRP3 inflammasome by islet amyloid polypeptide provides a mechanism for enhanced $\mathrm{IL}-1 \beta$ in type 2 diabetes. Nature Immunol. 2010;11:897-904

14. Araujo EP, De Souza CT, Ueno M, Cintra DE, Bertolo MB, Carvalheira JB, et al. Infliximab restores glucose homeostasis in an animal model of diet-induced obesity and diabetes. Endocrinology. 2007;148:991-7.

15. Winer DA, Winer S, Shen L, Wadia PP, Yantha J, Paltser G, et al. B cells promote insulin resistance through modulation of $T$ cells and production of pathogenic lgG antibodies. Nat Med. 2011;17:610-7.

16. Cohen NR, Garg S, Brenner MB. Antigen presentation by CD1 lipids, T cells, and NKT cells in microbial immunity. Adv Immunol. 2009;102:1-94.

17. Geddes K, Rubino SJ, Magalhaes JG, Streutker C, Le Bourhis L, Cho JH, et al. Identification of an innate $T$ helper type 17 response to intestinal bacterial pathogens. Nat Med. 2011;17:837-44.

18. Sjöberg K, Eriksson KF, Bredberg A, Wassmuth R, Eriksson S. Screening for coeliac disease in adult insulin-dependent diabetes mellitus. J Intern Med. 1998:243:133-40.

19. Page SR, Lloyd CA, Hill PG, Peacock I, Holmes GK. The prevalence of coeliac disease in adult diabetes mellitus. QJM. 1994:87:631-7.

20. Tourniaire J, Guichard-Rode S, Monier JC. Circulating antigliadin antibodies. Prevalence in a diabetic (type 1 or 2 ) and nondiabetic adult population. Presse Med. 1995;24:1425-7.

21. Kanungo A, Shtauvere-Brameus A, Samal KC, Sanjeevi CB. Autoantibodies to tissue transglutaminase in patients from eastern India with malnutritionmodulated diabetes mellitus, insulin-dependent diabetes mellitus, and noninsulin-dependent diabetes mellitus. Ann N Y Acad Sci. 2002:958:232-4.

22. Stratton IM, Adler Al, Neil HA, Matthews DR, Manley SE, Cull CA, et al. Association of glycemia with macrovascular and microvascular complications of Type 2 diabetes (UKPDS 35): Prospective observational study. BMJ. 2000;321:405-12.

23. Karter AJ, Moffet HH, Liu J, Parker MM, Ahmed AT, Ferrara A, et al. Achieving good glycemic control: Initiation of new antihyperglycemic therapies in the patient with Type 2 diabetes from the Kaiser Permanente Northern California diabetes registry. Am J Manag Care. 2005;11:262-70.

24. Koro CE, Bowlin SJ, Bourgeois N, Fedder DO. Glycemic control from 1988 to 2000 among US adults diagnosed with type2 diabetes: A preliminary report. Diabetes Care. 2004;27:17-20.

25. Wallace TM, Matthews DR. Poor glycemic control in Type 2 diabetes, conspiracy of disease, suboptimal therapy and attitude. Q J M. 2000;93:369-74.

26. Marsh MN. Gluten, major histocompatibility complex, and the small intestine. Gastroenterology. 1992;102:330-54.

27. Pietropaolo M, Barinas-Mitchell E, Pietropaolo SL, Kuller LH, Trucco M. Evidence of islet cell autoimmunity in elderly patients with type 2 diabetes. Diabetes. 2000;49:32-8.

28. Maedler K, Sergeev P, Ris F, Oberholzer J, Joller-Jemelka HI, Spinas GA, et al. Glucose-induced $\beta$-cell production of interleukin-1 $\beta$ contributes to glucotoxicity in human pancreatic islets. J Clin Invest. 2002;110:851-60.

29. Eldor R, Yeffet A, Baum K, Doviner V, Amar D, Ben-Neriah Y, et al. Conditional and specific NF-kB blockade protects pancreatic $\beta$ cells from diabetogenic agents. Proc Natl Acad Sci USA. 2006;103:5072-7.

30. Jagannathan M, McDonnell M, Liang Y, Hasturk H, Hetzel J. Rubin Det al.: Toll-like receptors regulate B-cell cytokine production in patients with diabetes. Diabetologia. 2010;53:1461-71.

31. Van Exel E, Gussekloo J, de Craen AJ, Frölich M. Bootsma-Van Der Wiel A, Westendorp RG; Leiden 85 Plus Study. Low production capacity of interleukin-10 associates with the metabolic syndrome and type 2 diabetes: the Leiden 85-Plus Study. Diabetes. 2002;51:1088-92.

32. Folk JE, Finlaynson JS. The e-(g-glutamyl) lysine cross-link and the catalytic role of transglutaminases. Adv Protein Chem. 1997;31:1-133.

33. Dvorcakova M, Macejova D, Pallet V, Hiqueret $\mathrm{P}$, Vasson MP, Rock E, et al. Transglutaminase and endocrine system (minireview). Endocr Regul. 2002;36:31-6.

34. Sener A, Dunlop ME, Gomis R, Matias PC, Malaisse-Lagae F, Malaisse WJ. The role of transglutaminase in insulin release. Study with glycine and sarcosine methylesters. Endocrinology. 1985:117:237-42.

35. Gomis R, Sener A, Malaisse-Lagae F, Malaisse WJ. Transglutaminase activity in pancreatic islets. Biochim Biophys Acta. 1983:8:384-8.

36. Rubio-Tapia A, Hill ID, Kelly CP, Calderwood AH, Murray JA. American College of G. ACG clinical guidelines: diagnosis and management of celiac disease. Am J Gastroenterol. 2013;108:656-76.

37. Bhadada SK, Kochhar R, Bhansali A, Dutta U, Kumar PR, Poornachandra KS, et al. Prevalence and clinical profile of celiac disease in type 1 diabetes mellitus in North India. J Gastroenterol Hepatol. 2011;26:378-81.

38. Usai P, Cherchi MV, Boi MF, Cirillo R, Santa Cruz G, Solinas MP, et al. Celiac disease in insulin-dependent diabetes mellitus and insulin-independent diabetes mellitus. Recenti Prog Med. 1989:80:56-8.

39. Sánchez JC, Cabrera-Rode E, Sorell L, Galvan JA, Hernandez A, Molina G, et al. Celiac disease-associated antibodies in persons with latent autoimmune diabetes of adult and type 2 diabetes. Autoimmunity. 2007;40:103-7.

\section{Submit your next manuscript to BioMed Central and we will help you at every step:}

- We accept pre-submission inquiries

- Our selector tool helps you to find the most relevant journal

- We provide round the clock customer support

- Convenient online submission

- Thorough peer review

- Inclusion in PubMed and all major indexing services

- Maximum visibility for your research

Submit your manuscript at www.biomedcentral.com/submit 